\title{
Testing of insect microsporidians (Microspora: Nosematidae) in nontarget aquatic species*
}

\author{
John W. Fournie ${ }^{1}$, Steven S. Foss ${ }^{1}$, Lee A. Courtney ${ }^{1}$, Albert H. Undeen ${ }^{2}$ \\ ${ }^{1}$ U.S. Environmental Protection Agency, Environmental Research Laboratory, Sabine Island, Gulf Breeze, Florida 32561, USA \\ ${ }^{2}$ U.S. Department of Agriculture, Agricultural Research Service, Insects Affecting Man and Animals Research Laboratory, \\ PO Box 14565, Gainesville, Florida 32604, USA
}

\begin{abstract}
This paper reports results of tests with the mosquito microsporidian Nosema algerae and the orthopteran microsporidian $N$. locustae on nontarget aquatic organisms. Organisms tested were the freshwater grass shrimp Palaemonetes kadiakensis, the estuarine grass shrimp P. pugio, the marine rotifer Brachionus plicatilis, and the inland silverside Menidia beryllina. These organisms were exposed by intrahemocoelic injection, gavage, or ingestion. Infections did not develop in either the freshwater grass shrimp or the estuarine grass shrimp that were gavaged with $N$. algerae spores. However, infections did develop in both species of grass shrimp after intrahemocoelic injections with $N$. algerae spores. Infected tissues included the gills, antennal gland, eyes, skeletal muscle, heart, and gonads. Proof of infection was demonstrated ultrastructurally by the presence of mature spores and developmental stages in infected tissues. Infections did not develop in $P$. pugio following intrahemocoelic injections of $N$. locustae spores. $N$. algerae infections did not develop in the marine rotifer after ingestion of spores or in inland silversides fed marine rotifers containing ingested spores.
\end{abstract}

\section{INTRODUCTION}

Microbial pest control agents (MPCAs) are becoming increasingly important as substitutes for chemical pesticides. Because these agents may be applied in large quantities over wide geographical areas, methods must be developed to evaluate their safety for nontarget species (Korp 1975, Environmental Protection Agency 1982). The U.S. Environmental Protection Agency is responsible for providing registration guidelines to potential producers of MPCAs for methods to determine the safety of the agents to nontarget species in the USA.

Because insect microsporidians are presently being used as MPCAs and others may be developed, knowledge of their total potential host range and safety to nontarget organisms must be demonstrated. Nosema algerae is a microsporidian of some species of mosquitoes which at one time was being evaluated as a biologic control agent. $N$. locustae is a parasite of a

- Contribution No. 680, Gulf Breeze Environmental Research Laboratory

- Mention of commercial products or company names does not imply endorsement by the U.S. Environmental Protection Agency or the U.S. Department of Agriculture number of different orthopterans and is a registered MPCA (Nolo Bait ${ }^{\circledR}$ ) $\cdots$. Undeen \& Maddox (1973) have shown that insects of several different orders, as well as crayfish, were susceptible to $N$. algerae infection when spores were injected into the hemocoel. Because of these findings, we explored the potential infectivity of these microsporidians in other nontarget aquatic species.

This paper reports on studies involving the injection and gavage of Nosema algerae spores into nontarget grass shrimp Palaemonetes pugio and P. kadiakensis, injection of $N$. locustae into $P$. pugio and the feeding of spores to the marine rotifer Brachionus plicatilis to determine if infections would develop. Attempts were also made to produce infections in the inland silverside Menidia beryllina by feeding them rotifers which had ingested spores.

\section{MATERIALS AND METHODS}

Nontarget test organisms. Organisms tested included the freshwater grass shrimp Palaemonetes kadiakensis, the estuarine grass shrimp $P$. pugio, the marine rotifer Brachionus plicatilis, and the inland sil- 
verside Menidia beryllina. Grass shrimp were collected with dip nets and pole seines from shallow waters of creeks and estuaries in northwest Florida, USA. Shrimp were transported to the laboratory and held in a $112 \mathrm{I}$ aquarium for at least $1 \mathrm{wk}$ prior to testing. Baseline samples were examined microscopically to determine if shrimp had any naturally occurring microsporidian infections. Marine rotifers and inland silversides were obtained from laboratory cultures.

Preparation of spore suspensions. Two microsporidians were utilized in testing, Nosema algerae and $N$. locustae. $N$. algerae spores were isolated from corn earworms Heliothis zea previously infected by feeding spores to starved third instar larvae (Anthony et al. 1978). To avoid contamination of spores during collection, the external surfaces of infected corn earworms were sterilized by dipping the insect into a $25 \%$ sodium hypochlorite solution. Insects were then rinsed in distilled water, pinned to a sheet of paraffin, and the ventral abdomen carefully opened under a dissecting microscope. Infected tissues, primarily fat bodies, were removed with forceps and placed in sterile $4 \mathrm{ml}$ test tubes containing ca $1 \mathrm{ml}$ of $0.025 \mathrm{M} \mathrm{NaOH}$ solution. After $30 \mathrm{~min}$, the spores were harvested by centrifugation at $1000 \times \mathrm{g}$ for $10 \mathrm{~min}$. The $\mathrm{NaOH}$ was decanted and spores were resuspended in distilled water. Final spore suspensions were quantified with a hemacytometer and stored at $5^{\circ} \mathrm{C}$ until use.

A simple salinity tolerance test was conducted to determine if Nosema algerae spores would germinate at salinities normally encountered in an estuarine environment. Approximately 2.0 to $4.0 \mu \mathrm{l}$ of spore suspension with a concentration of $1.0 \times 10^{9}$ spores $\mathrm{ml}^{-1}$ were added to each of 8 tubes containing $0.5 \mathrm{ml}$ of artificial seawater with salinities of $5,10,15,20,25$, and 30 parts per thousand $(\%)$; both tap water and distilled water were also tested. The solutions containing spores were allowed to incubate at room temperature for $1 \mathrm{~h}$; samples were then examined using phase contrast microscopy to determine if germination had occurred as indicated by their dark appearance and the presence of an extruded polar filament.

Concentrated suspensions of Nosema locustae spores were obtained from Dr D. A. Streett, U.S Department of Agriculture, Montana State University Rangeland Insect Laboratory, Bozeman, Montana, USA, and Evans BioControl, Broomfield, Colorado, USA . Spores were received as purified spore suspensions at concentrations of $1 \times 10^{9}$ and $1 \times 10^{10}$ spores $\mathrm{ml}^{-1}$, respectively Working spore suspensions, prepared by serial dilution of the concentrated preparations, were quantified with a hemacytometer and stored at $5^{\circ} \mathrm{C}$ until used.

Gavage and injection of grass shrimp. Groups of freshwater and estuarine grass shrimp were exposed to
Nosema algerae spores by both gavage and intrahemocoelic injection. Groups of Palaemonetes pugio were exposed to $N$. locustae spores by intrahemocoelic injection only.

Gavage studies were performed using a microliter syringe with a blunt tipped, 25 -gauge needle. The needle was inserted in to the mouth of each shrimp and a calibrated dose of a quantified spore suspension was introduced, under a dissecting microscope, into the alimentary tract to minimize injury to shrimp. Shrimp received a $20 \mu \mathrm{l}$ dose of Nosema algerae spore suspension containing $3.1 \times 10^{4}$ spores, and a group of control shrimp was gavaged with $20 \mu \mathrm{l}$ of sterile saline-solution.

Injected spore dosages were delivered with a $1 \mathrm{cc}$ tuberculin syringe eguipped with a 25 -gauge needle. and mounted on a microinjector pump. The syringe was rotated frequently to prevent settling of spores. Shrimp were injected by inserting the needle under the carapace at the posterior margin of the cephalothorax. Exposed shrimp received $2.0 \mu \mathrm{l}$ of Nosema algerae spore suspension containing ca $3.6 \times 10^{3}$ spores, and controls were injected with $2.0 \mu \mathrm{l}$ of sterile salinesolution. Three injection experiments were conducted with $N$. locustae with shrimp receiving ca 6 to $7 \mu \mathrm{l}$ of spore suspension per injection. Dosage was $4.0 \times 10^{3}$ spores injection ${ }^{-1}$ for the first 2 sets of injections, and $1.5 \times 10^{5}$ spores injection $^{-1}$ for the third.

Both gavaged and injected shrimp were held in small, aerated aquaria for 3 to $4 \mathrm{~h}$ before surviving shrimp were transferred to static holding tanks. Water temperature and salinity were maintained at ca $26^{\circ} \mathrm{C}$ and $25 \%$, respectively. Shrimp were sampled every $7 \mathrm{~d}$ and either examined by fresh-squash or processed for histological examination; moribund shrimp were also examined microscopically. Samples of tissues determined by fresh squash to contain spores were isolated and processed for ultrastructural examination.

Rotifer and fish exposures. To determine if rotifers could ingest and/or be infected with Nosema algerae spores, two $250 \mathrm{ml}$ Erlenmeyer flasks each containing ca $4.0 \times 10^{4}$ rotifers in $100 \mathrm{ml}$ of $25 \%$ filtered seawater at $22^{\circ} \mathrm{C}$ were used. The experimental flask received $1 \mathrm{~m}$. of spore suspension containing ca $1.7 \times 10^{6}$ spores; the control flask received $1 \mathrm{ml}$ of distilled water. After $2 \mathrm{~h}$, a sample was taken and examined microscopically to determine if rotifers, which are transparent, ingested spores. After $36 \mathrm{~h}$, samples from both flasks were examined by electron microscopy to determine if spore germination and infection resulted.

Finally, a simple experiment was conducted to determine if the inland silverside Menidia beryllina could be infected with Nosema algerae by ingesting rotifers which had fed on spores. Two groups of 40 fish were placed into $4.3 \mathrm{l}$ battery jars. The experimental group received ca $2.0 \times 10^{4}$ rotifers with ingested spores; the 
control group received rotifers without spores. Both groups of fish were allowed to feed on the rotifers for $4 \mathrm{~h}$ before transfer to $80 \mathrm{l}$ flow-through aquaria. They were fed Artemia nauplii daily. After $4 \mathrm{wk}$, all fish were fixed and processed for histologic examination.

Histologic and ultrastructural procedures. Animals to be examined by light microscopy were fixed for ca 48 h in either Bouin's solution (Luna 1968) or Davidson's solution (Shaw \& Battle 1957). Fish were decalcified for ca $48 \mathrm{~h}$ in Cal-Ex ${ }^{(B)}$ and shrimp in a decalcifying solution consisting of 1 part formic acid, 1 part $95 \%$ ethyl alcohol, and 1 part $10 \%$ sodium acetate in $1 \%$ trichloroacetic acid. Tissues were then dehydrated, embedded in paraffin, and sectioned at $6 \mu \mathrm{m}$. Sections were stained with Harris' hematoxylin and eosin or Brown and Brenn tissue Gram-stain (Luna 1968).

Tissues to be examined by electron microscopy were fixed with $3 \%$ glutaraldehyde in $0.2 \mathrm{M}$ sodium cacodylate buffer ( $\mathrm{pH} 7.4$ ), postfixed in $1 \%$ osmium tetroxide, dehydrated in a graded acetone series, and then embedded in Spurr's epoxy resin. Thick sections stained with toluidine blue were used to identify tissue and locate sites of infection. Ultrastructural observations of 50 to $60 \mathrm{~nm}$ sections stained with uranyl acetate and lead citrate (Hayat 1981) were made on a Zeiss EM10 electron microscope

\section{RESULTS}

\section{Spore germination in seawater}

Germination of Nosema algerae spores occurred in all seawater solutions tested ( 5 to $30 \%$ ). Germination was indicated by darkening of the spores and/or visualization of the extruded polar filaments using phase contrast microscopy. Approximately $20 \%$ of spores germinated at the lower salinities and up to $50 \%$ at the higher. Minimal germination occurred in tap water $(5 \%)$ and no germination was observed in spores incubated in distilled water.

\section{Gavage and injection studies}

None of the grass shrimp gavaged with dosages of Nosema algerae spores developed infections, and the number of deaths was low for both species of shrimp (Table 1). Additionally, there was no substantial difference in mortality between the saline and sporegavaged shrimp.

Intrahemocoelic injections of Nosema algerae spores produced $100 \%$ mortality (excluding individuals sacrificed for histology) in both Palaemonetes pugio and $P$. kadiakensis (Table 2). All P. pugio died by Day 8 post-
Table 1. Palaemonetes spp. Mortality of palaemonid shrimp gavaged with Nosema algerae. Dosage $=31000$ spores shrimp $^{-1}$

\begin{tabular}{|lcccc|}
\hline Species & $\begin{array}{c}\text { No. } \\
\text { injected }\end{array}$ & $\begin{array}{c}\text { No. } \\
\text { dead }\end{array}$ & $\begin{array}{c}\text { No. } \\
\text { examined }\end{array}$ & $\begin{array}{c}\text { No. } \\
\text { infected }\end{array}$ \\
\hline \multicolumn{2}{l}{ Paldemonetes pugio } & & & \\
Controls & 20 & 4 & 16 & 0 \\
Gavaged & 20 & 2 & 10 & 0 \\
Palaemonetes kadiakensis & & & \\
Controls & 20 & 0 & 10 & 0 \\
Gavaged & 40 & 4 & 10 & 0 \\
\hline
\end{tabular}

Table 2. Palaemonetes spp. Mortality of palaemonid shrimp injected with Nosema algerae. Dosage $=3600$ spores shrimp ${ }^{-1}$

\begin{tabular}{|lcccc|}
\hline Species & $\begin{array}{c}\text { No. } \\
\text { injected }\end{array}$ & $\begin{array}{c}\text { No. } \\
\text { dead }\end{array}$ & $\begin{array}{c}\text { No. } \\
\text { examined }\end{array}$ & $\begin{array}{c}\text { No. } \\
\text { infected }\end{array}$ \\
\hline Palaemonetes pugio & & & \\
Controls & 20 & 5 & 14 & 0 \\
Injection 1 & 20 & 16 & 4 & 4 \\
Injection 2 & 19 & 12 & 7 & 7 \\
Palaemonetes & kadiakensis & & & \\
Controls & 17 & 5 & 10 & 0 \\
Injected & 35 & 27 & 8 & 7 \\
\hline
\end{tabular}

injection and all P. kadiakensis were dead by Day 6 post-injection. An obvious difference in mortality occurred between saline-injected controls and sporeinjected grass shrimp. Approximately $92 \%$ of grass shrimp examined histologically exhibited infections with $N$. algerae. Spores of the microsporidian were observed in numerous tissues and organs, including the heart (Fig. 1), gills, antennal gland (Fig. 2), eyes, skeletal musculature (Fig. 3), and gonads (Fig. 4). Injections of $N$. locustae spores produced no infections in the estuarine grass shrimp $P$. pugio (Table 3 ).

Ultrastructural examination of Nosema algerae infected tissues revealed various developmental stages of the microsporidian. Fig. 5 illustrates binucleate sporonts, crenated sporoblasts, and mature spores containing polar filaments. Sporonts were the most common stage observed with electron microscopy and were characterized by a pair of nuclei in close apposition causing the appearance of a 'ridge'; nuclear membranes were uninterrupted (Fig. 6).

\section{Rotifer and fish exposures}

Nosema algerae spores were observed in the alimentary tract of marine rotifers (Brachionus plicatilis) after 


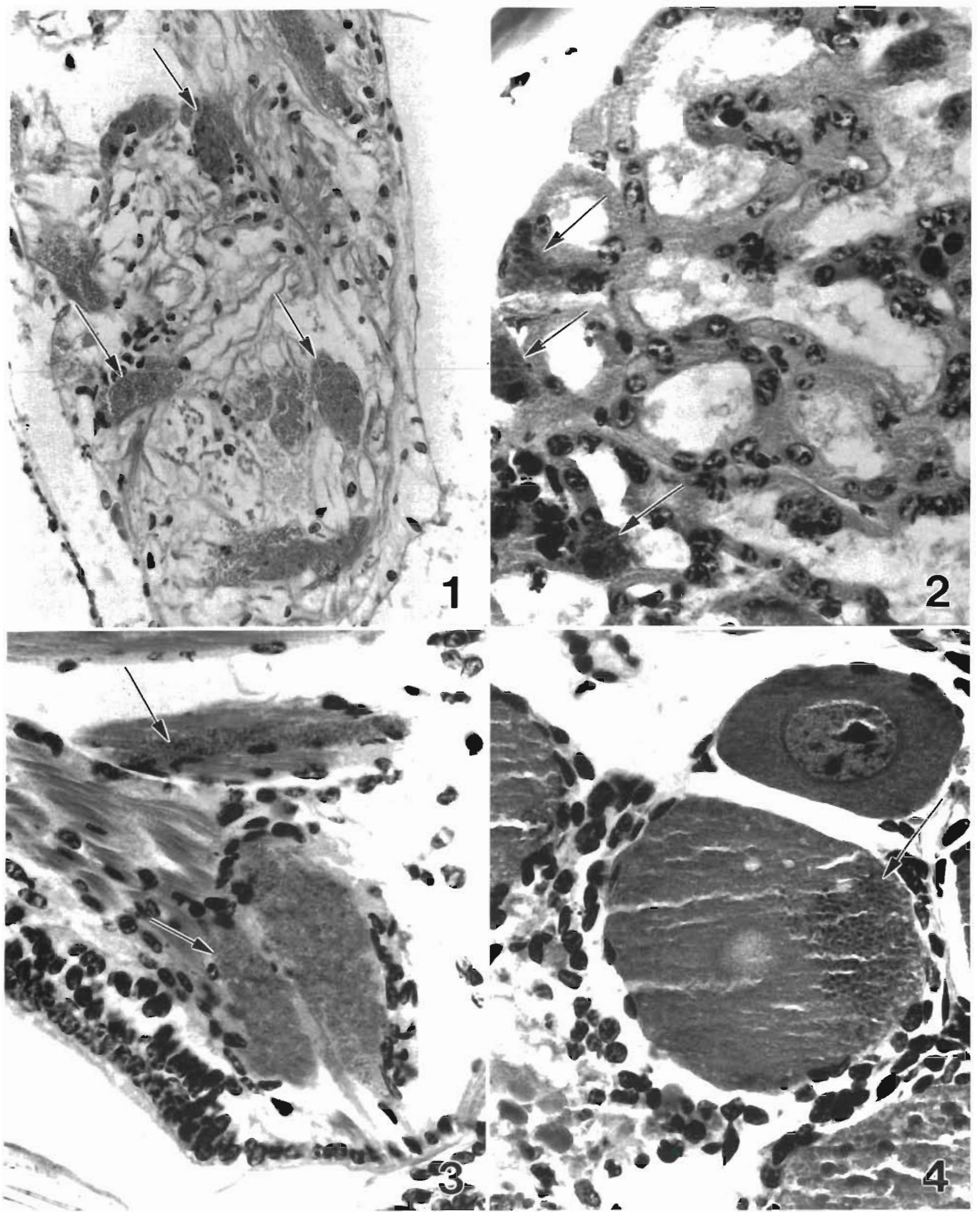

Figs. 1 to 4 Palaemonetes pugio and $P$. kadiakensis. Histologic sections through grass shrimp; H \& E. Fig. 1. Longitudinal section through heart of $P$. pugio showing numerous packets of Nosema algerae spores (arrows) scattered throughout the cardiac tissues; $\times$ 156. Fig. 2. Section through antennal gland of $P$. pugio infected with $N$. algerae (arrows); $\times 312$. Fig. 3 . Numerous packets of $N$ algerae spores (arrows) in sections of skeletal muscle from injected freshwater grass shrimp, P. kadiakensis; $\times 156$. Fig. 4. Oocyte from $P$. kadiakensis infected with $N$. dlgerae spores (arrow): $\times 312$ 


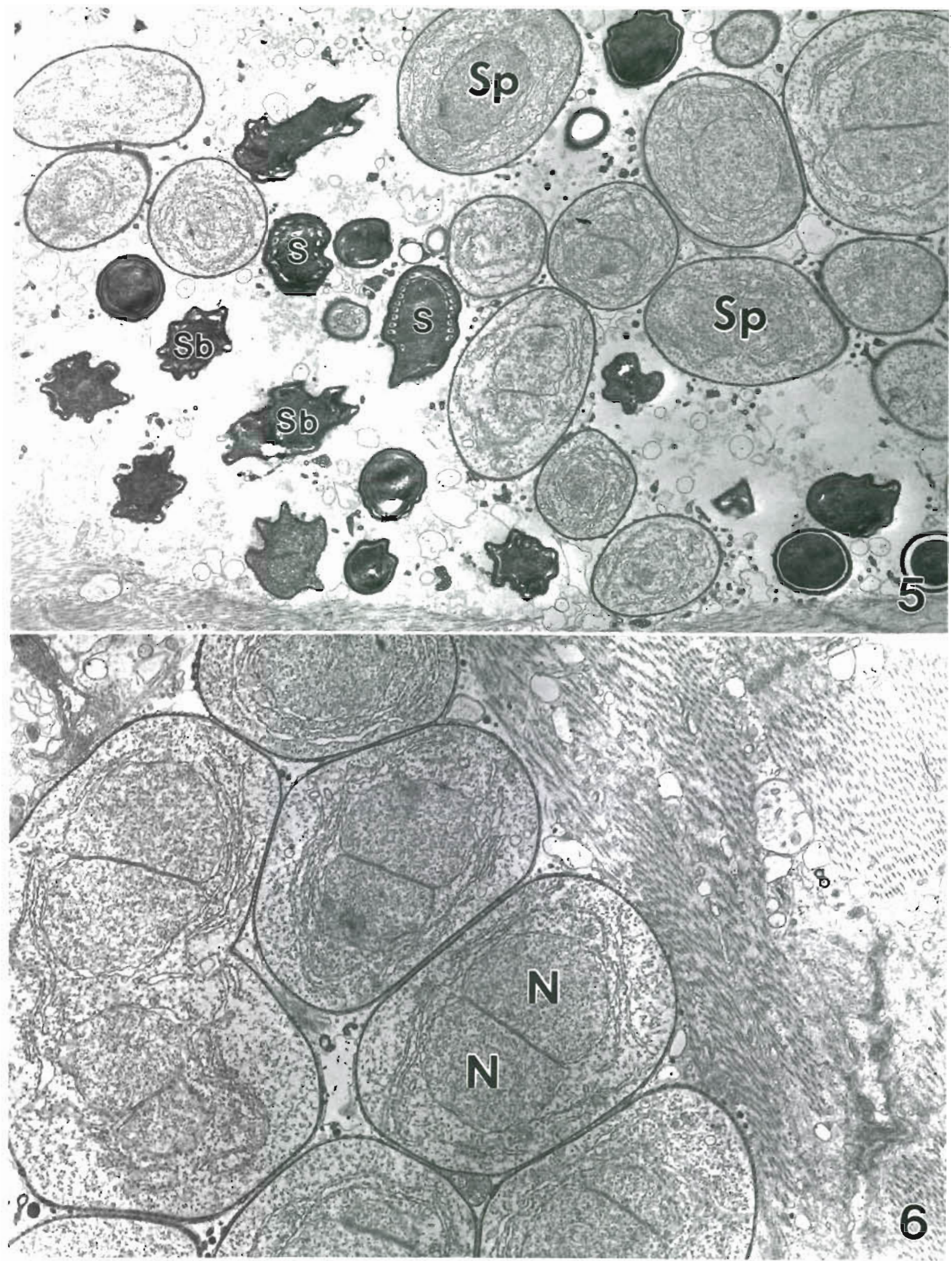

Figs. 5 and 6. Palaemonetes kadıakensis Fig. 5. Low power electron micrograph showing developmental stages of Nosema algerae in grass shmmp uncluding sporonts (Sp), crenated sporoblasts (Sb), and mature spores (S), $\times 6300$ Flg. 6 Higher power electron micrograph of skeletal muscle showing binucleate sporonts of Nosema algerae. The 2 nucles ( $N$ ) of the diplokaryon are in close apposition causing the appearance of a 'ndge'. Nuclear membranes are not interrupted; $\times 9400$ 
Table 3. Palaemonetes pugio. Mortality of individuals injected with Nosema locustae. Dosage: Injection 1, $2=4000$ spores shrimp $^{-1}$; Injection 3: 150000 spores shrimp ${ }^{-1}$

\begin{tabular}{|ccccc|}
\hline Treatment & $\begin{array}{c}\text { No. } \\
\text { injected }\end{array}$ & $\begin{array}{c}\text { No. } \\
\text { dead }\end{array}$ & $\begin{array}{c}\text { No. } \\
\text { examined }\end{array}$ & $\begin{array}{c}\text { No. } \\
\text { infected }\end{array}$ \\
\hline Injection 1 & 13 & 0 & 12 & 0 \\
Injection 2 & 24 & 8 & 16 & 0 \\
Injection 3 & 24 & 5 & 15 & 0 \\
Total & 61 & 13 & 43 & 0 \\
\hline
\end{tabular}

exposure to spore suspension for $2 \mathrm{~h}$ (Fig. 7). However after $36 \mathrm{~h}$, no spores could be observed in the alimentary tract of rotifers. Thick sections of plastic-embedded rotifers sampled at $36 \mathrm{~h}$ also failed to reveal mature spores or any developmental stages of microsporidian. Germination experiments indicated that at $25 \% \mathrm{ca}$ $50 \%$ spore germination occurred within $1 \mathrm{~h}$. Therefore, induced spore germination could possibly account for the absence of spores observed at $36 \mathrm{~h}$. However, it is also possible that the ingested spores might have been discharged in less than $36 \mathrm{~h}$.

Histologic sections of Menidia beryllina that fed on rotifers containing Nosema algerae spores showed no signs of infection.

\section{DISCUSSION}

No macroscopic or microscopic evidence of infectivity, pathogenicity, or toxicity was noted in grass shrimp that were gavaged with viable Nosema algerae spores. This was expected because at least several barriers to infection exist when a microsporidian spore is ingested. First, conditions of the gut contents must be conducive to spore germination; second, the sporoplasm must be able to penetrate the gut epithelium; and, third, the host tissues must be able to support development of the parasite. However, the possibility that grass shrimp might be infected after gavage dosages of spores required investigation because another nonnatural host. Heliothis zea, is routinely inferted per no (Anthony et al. 1978).

Intrahemocoelic injections of Nosema algerae spores produced $100 \%$ mortality in both species of grass shrimp, and ca $92 \%$ of these shrimp examined histologically revealed infections. Similar results were reported by Undeen \& Maddox (1973). Infections developed in $100 \%$ of crayfish injected with $N$. algerae spores; all died ca $14 \mathrm{~d}$ after injection. The most heavily infected tissue in the crayfish was the gills, which was purported to be the cause of mortality. Gills of both species of grass shrimp exhibited light infections with

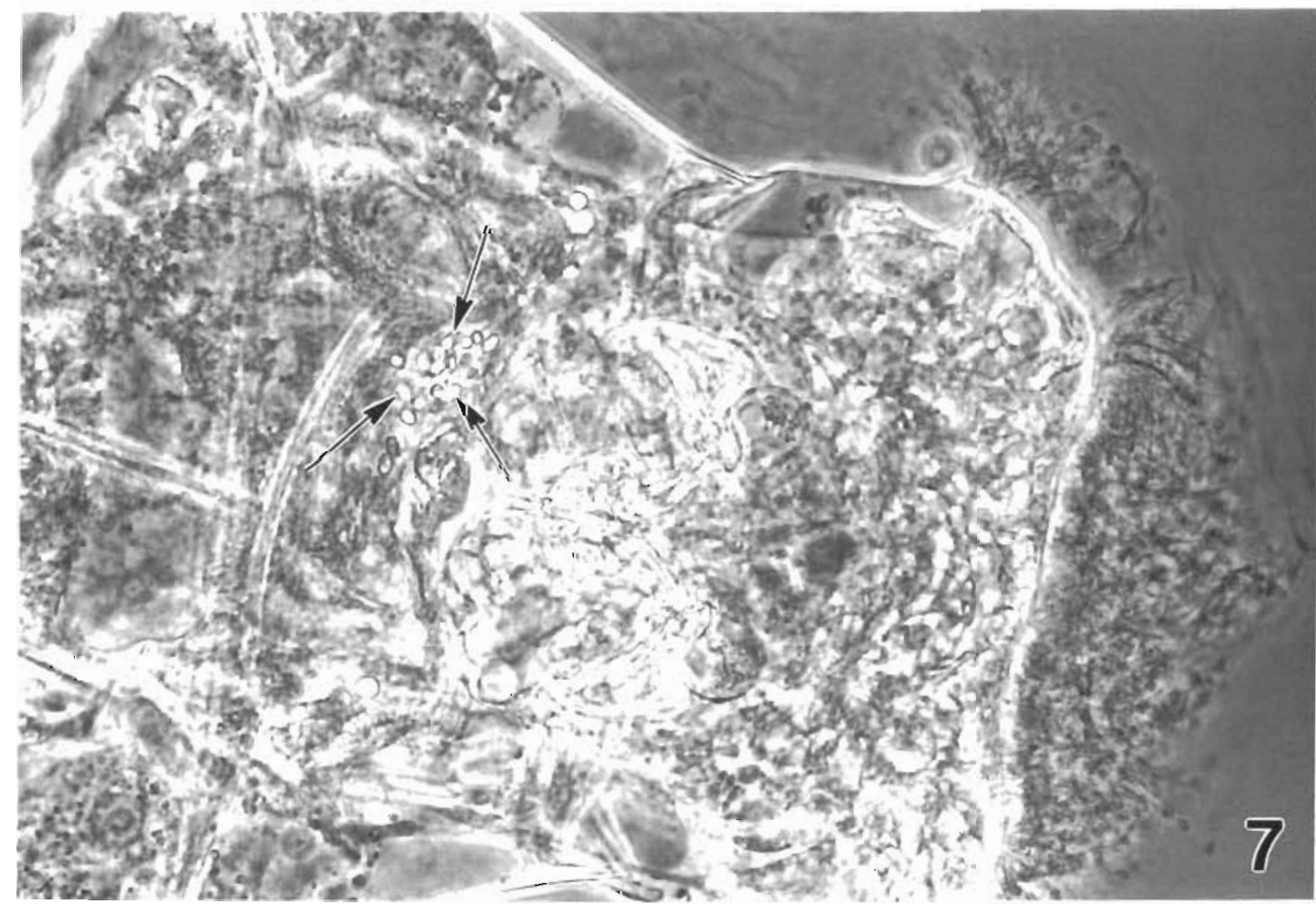

Fig. 7 Brachionus plicatilis. Whole mount of the marine rotifer sampled following ingestion of Nosema algerae spores (arrows); $\times 500$ 
$N$. algerae; the most heavily infected tissues were the heart and skeletal musculature.

Heavily infected shrimp tissues were easily and reliably identified with fresh-squash techniques. Ultrastructural examination of tissues identified by this method confirmed these findings. The 3 major stages of Nosema algerae reported from Anopheles stephensi, its natural host (Vavra \& Undeen 1970), were documented in musculature and gill from both Palaemonetes pugio and $P$. kadiakensis. Routine hematoxylin and eosin preparations provided reliable identification of moderate to heavy infections in numerous tissues. Histological sections stained with the Brown and Brenn tissue Gram-stain were valuable in identification of tissues containing low numbers of spores because they stain dark blue just as Gram positive bacteria, contrasting sharply with the yellow background stain.

Some microsporidian spores become more infective to the proper host after they pass through or remain in certain nonsusceptible 'hosts' (Scarborough \& Weidner 1979). Additionally, Weissenberg (1968) infected young stickleback larvae with the microsporidian Glugea anomala by feeding them Cyclops sp. and Daphnia sp. which had fed on suspensions of spores. Because certain small crustaceans may serve as intermediate or paratenic hosts in the life cycles of some microsporidians, we attempted to infect inland silversides by feeding them rotifers which had ingested Nosema algerae spores. Even though we failed to produce infections, the possibility does exist that a microsporidian being used or developed as an MPCA might become more infective to a nontarget host after passing through or remaining in a small crustacean.

A number of good reasons exist for studying effects of entomophilic microsporidians on nontarget hosts. Insect microsporidians are being considered and developed as MPCAs. For example, Nosema algerae has been evaluated for control of mosquitoes, some of which serve as vectors for malaria (Undeen \& Alger 1975). Additionally, $N$. locustae is a registered MPCA (Nolo Bait $\left.{ }^{(}\right)$and is widely used to control the rangeland grasshopper. Because microsporidians are ubiquitous parasites of almost every phylum of invertebrate animal and in all classes of vertebrates, and because new information is available concerning several aspects of the biology of the Microsporida, possible effects of these parasites on nontarget animals requires investigation. Previously, it was believed that life cycles of all microsporidia were monoxenous (Canning 1977) and that these parasites were relatively host specific. However, there is increasing evidence that microsporidia are cross-infective between hosts (Canning 1977) and that some life cycles are heteroxenous, requiring one or more intermediate hosts (Sweeney et al. 1985). Further evidence suggesting the lack of host specificity in microsporidians is provided by Ishihara (1968) who demonstrated the growth of $N$. bombycis in primary cell cultures of both rat and chicken embryos and Undeen (1975) who demonstrated that $N$. algerae spores germinated, infected cells, multiplied, and produced spores in pig kidney cell cultures. Together, these findings suggest that there is a greater possibility of infectivity, pathogenicity, or toxicity resulting in nontarget hosts exposed to microsporidian MPCAs, therefore indicating that continued development and refinement of nontarget testing are necessary to ensure environmental safety of commercial MPCAs.

Acknowledgements. We thank Dr D. P. Middaugh, U.S Environmental Protection Agency, Environmental Research Laboratory, Gulf Breeze, Florida, USA, for providing fish and rotifers used in these experiments.

\section{LITERATURE CITED}

Anthony, D. W., Savage, K. E., Hazard, E. I., Avery, S. W., Boston, M. D., Oldacer, S. W. (1978). Field tests with Nosema algerae Vavra and Undeen (Microsporidia, Nosematidae) against Anopheles albimanus Weidmann in Panama. In: Brooks, W M. (ed.) Selected topics on the genus Nosema (Microsporidia). Misc. Publ. Ent. Soc. Am. 11: $17-28$

Canning, E. U. (1977). Microsporida. In: Kreier, J. P. (ed.) Parasitic Protozoa. IV. Babesia, Theileria, Myxosporida, Microsporida, Bartonellaceae, Anaplasmataceae, Ehrlichia, and Pneumocystis. Academic Press Inc., New York, p. $155-196$

Environmental Protection Agency (1982). Pesticide assessment guidelines, subdivision $\mathrm{M}$, biorational pesticides. Office of Pesticides and Toxic Substances, Washington, D.C.

Hayat, M. A. (1981). Principles and techniques of electron microscopy: biological applications. Vol. 1, 2nd edn. University Park Press, Baltimore

Ishihara, R. (1968). Growth of Nosema bombycis in primary cell cultures of mammalian and chicken embryos. J. Invertebr. Path. 11: 328-329

Korp, H. (1975). Introductory remarks. In: Summers, M. (ed.) Baculoviruses for insect pest control: safety considerations. Am. Soc. Microbiol., Washington, D.C., p. 3

Luna, L. G. (1968). Manual of histologic staining methods of the Armed Forces Institute of Pathology, 3rd edn. McGraw Hill, New York

Scarborough, A., Weidner, E. (1979). Field and laboratory studies of Glugea hertwigi (Microsporida) in the rainbow smelt Osmerus mordax. Biol. Bull. mar. biol. Lab., Woods Hole 157: 334-343

Shaw, B. L., Battle, H. I. (1957). The gross and microscopic anatomy of the digestive tract of the oyster Crassostrea virginica (Gmelin). Can. J. Zool. 35: 325-347

Sweeney, A. W., Hazard, E. I., Graham, M. F. (1985). Intermediate host for an Amblyospora sp. (Microspora) infecting the mosquito, Culex annulirostris. J. Invertebr Path. 46: $98-102$

Undeen, A. H. (1975). Growth of Nosema algerae in pig kidney cell cultures. J. Protozool. 22: 107-110 
Undeen, A. H., Alger, N. E. (1975). The effect of the Microsporidian, Nosema algerae, on Anopheles stephensi. J. Invertebr Path. 25: 19-24

Undeen, A. H., Maddox, J. V. (1973). The infection of nonmos quito hosts by injection with spores of the microsporidian Nosema algerae. J. Invertebr. Path. 22: 258-265

Vavra, J., Undeen, A. H. (1970). Nosema algerae n. sp

Responsible Subject Editor: Professor O. Kinne, Oldendorf/ Luhe, F. R. Germany
(Cnidospora, Microsporida) a pathogen in a colony of Anopheles stephensi Liston (Diptera, Culicidae). J. Protozool. 17: $240-249$

Weissenberg, R. (1968). Intracellular development of the microsporidian Glugea anomala Moniez in hypertrophying migratory cell formation of 'xenoma' tumours. J. Protozool. 15: $44-57$

Manuscript first received: October 31, 1989

Revised version accepted: December 29, 1989 